ISSN: 2085-0344 (Print)

ISSN: 2503-1864 (Online)

Journal homepage: www.ejournal.almaata.ac.id/literasi

Journal Email: literasi_stia@yahoo.com

\title{
Pola Pembinaan Religiusitas Anak dalam Keluarga Muslim (Studi Kasus di Kampung Kesisih Desa Bangunsari, Pageruyung, Kendal, Jawa Tengah)
}

\author{
Iqbal Rezza Fahlevie ${ }^{1 *}$, Tasman Hamami ${ }^{2}$ \\ ${ }^{1}$ Program Pasca Sarjana, Universitas Muhammadiyah Yogyakarta, \\ ${ }^{2}$ UIN Sunan Kalijaga Yogyakarta \\ *balrevie@gmail.com
}

\begin{abstract}
Abstrak
Penelitian ini bertujuan untuk mengetahui kondisi psikologi keluarga muslim dan kesulitan yang muncul dalam proses pembinaan religiusitas anak, serta menemukan pola pembinaan religiusitas anak dalam keluarga muslim. Penulis menggunakan penelitian kualitatif dengan pendekatan etnografi. Pengumpulan data dilakukan dengan teknik observasi, wawancara, dan dokumentasi. Analisis data kualitatif dalam penelitian ini dilakukan secara simultan dengan proses pengumpulan data. Analisis data yang digunakan dalam penelitian ini adalah Analysis Interactive Model dari Miles dan Huberman. Langkah-langkah dalam kegiatan analisis data meliputi: pengumpulan data (data collection), reduksi data (data reduction), penyajian data (data display), dan penarikan kesimpulan atau verifikasi (conclutions). Hasil penelitian ini adalah: (1) kondisi psikologi keluarga muslim (orang tua) yang terjadi dalam keluarga adalah mengalami trauma psikis dan kekecewaan dalam berumah tangga (keluarga single parent), kondisi kemiskinan; dan jarak lokasi perkerjaan yang jauh dengan keluarga. (2) kesulitan-kesulitan yang muncul dalam proses pembinaan religiusitas anak meliputi kurangnya kebersamaan orang tua dan anak, adanya pegaruh lingkungan sekitar dan pergaulan teman sebaya, serta tidak adanya sesosok ayah sebagai panutan dalam keluarga. (3) pola pembinaan religiusitas anak di dalam keluarga muslim yang lazim diterapkan adalah: (1) pola pembinaan demokrasi (2) pola pembinaan otoriter (3) pola pembinaan permisif.
\end{abstract}

Kata Kunci: bimbingan pembinaan, religiusitas, keluarga muslim

\begin{abstract}
This research aims to determine the condition of Muslim family psychology and the difficulties that arise in the process of formation of children's religiality, and to find a pattern of formation of children's religiality in Muslim families. The author uses qualitative research with an ethnographic approach. Data collection is done by observation techniques, interviews, and documentation. Qualitative data analysis in this study is done simultaneously with the data collection process. The anlysis of data used in this research is the Analysis Interactive Model of Miles and Huberman. The steps in data analysis activities include data collection, data reduction, data presentation (display data), and conclusion or verification (conclutions). The results of this research are: (1) The psychological condition of the Muslim family (parents) that occur in the family is to experience psychic trauma and disappointment in a married (single parent), poverty condition; and distance to the location of a distant work with the family. (2) The difficulties that arise in the process of development of children's religiality include the lack of the togetherness
\end{abstract}


of parents and children, the presence of environmental and peer associations, and the absence of a father as a role model in the family. (3) The pattern of formation of child religiality in a Muslim family that is commonly applied is: (1) Pattern of Coaching Democracy (2) pattern of authoritarian coaching (3) pattern of permissive coaching.

Keywords: coaching pattern, child religiusisity, Muslim family.

\section{PENDAHULUAN}

Keluarga merupakan kelompok sosial terkecil dari masyarakat yang mendapat tempat mapan dalam ajaran Islam. ${ }^{1}$ Pada umumnya, keluarga terdiri dari bapak atau suami, ibu atau istri dan anak yang memiliki hubungan tetap. Hubungan tersebut berdasarkan ikatan perkawinan, hubungan darah ataupun melalui proses adopsi dari luar keluarga tersebut. Keluarga yang dibentuk dari proses pernikahan merupakan suatu usaha untuk membentuk keluarga baru yang harmonis.

Pendidikan agama merupakan bidangbidang pendidikan yang wajib mendapat perhatian lebih oleh orang tua. Pendidikan agama sesungguhnya adalah penanaman iman ke dalam jiwa anak, dan untuk melaksanakan hal itu secara maksimal salah satunya dapat dilaksanakan di dalam lingkungan rumah tangga. Di sinilah orang tua berperan dalam membina dan mengarahkan anak-anak mereka untuk lebih mendalami makna keimanan sesuai dengan agama yang dianutnya. Bagaimanapun sederhananya pendidikan agama yang orang tua diberikan di rumah, pastilah hal itu akan berguna bagi anak.

Pembinaan merupakan usaha tindakan dan kegiatan yang dilakukan secara berdaya guna untuk memperoleh hasil yang baik. ${ }^{2}$ Pembinaan yaitu usaha manusia secara sadar untuk membimbing dan mengarahkan kepribadian serta kemampuan anak, baik dalam pendidikan formal maupun non formal. ${ }^{3}$

1 Anis, Muh. 2009. Sukses Mendidik Anak. (Yogyakarta: PT Pustaka Insan Madani). h. 9

2 Dendy Sugiono, Kamus Besar Bahasa Indonesia Pusat Bahasa edisi keempat (Jakarta: PT. Gramedia Utama, 2008).h. 134

3 M Arifin, Hubungan Timbal Balik Pendidikan Agama (Jakarta: Bulan Bintang, 2008), h. 30
Religiusitas merupakan suatu sistem yang kompleks dari kepercayaan keyakinan dan sikap-sikap dan upacara-upacara yang menghubungkan individu dari satu keberadaan atau kepada sesuatu yang bersifat keagamaan. ${ }^{4}$

Pembinaan religiusitas ini dapat dilakukan di rumah, di masyarakat, di rumah ibadah maupun di sekolah. Tetapi pembinaan yang paling penting dengan frekuensi paling tinggi untuk pembinaan tentu adalah yang dilaksanakan di rumah. Sedangkan di masyarakat, sekolah maupun rumah ibadah hanyalah merupakan wadah atau tempat pendukung, dimana materi maupun nilai-nilai agama tersebut diberi dan dicontohi dalam keseharian.

Namun pada kenyataannya, bentuk dari kewajiban sebagai orang tua terhadap anak yang merupakan amanah dari Allah SWT di kalangan masyarakat khususnya lingkungan keluarga muslim, melalui tindakan pembinaan masih terasa kurang mendapatkan perhatian khusus. Banyak alasan mengapa orang tua kurang memberikan perhatian khusus pada anakanak mereka, di antaranya adalah kesibukan orang tua dalam bekerja untuk mencari nafkah serta memenuhi kebutuhan hidup keluarga sehari-hari, pengetahuan orang tua yang tidak memadahi, dan lain sebagainya.

Melihat fenomena dan dari latar belakang di atas, penulis beranggapan bahwa hal ini menjadi perlu dan penting untuk adanya penelitian yang bersifat etnografis, yakni ingin memperlihatkan dan mendiskripsikan budaya dan norma-norma kehidupan pada sebuah masyarakat, dan memahami cara masyarakat berinteraksi dan bekerjasama melalui kejadian

4 Zakiah Daradjat, Ilmu Jiwa Agama, (Jakarta: Bulan Bintang, 1993).h. 29 
teramati dalam kehidupan sehari-hari, ${ }^{5}$ sebagai upaya menghadirkan tambahan informasi tentang pola pembinaan religiusitas anak dalam keluarga muslim.

Di kabupaten Kendal, tepatnya di Kampung Kesisih, desa Bangunsari kecamatan Pageruyung berdasarkan sudut pandang etnografis ada sesuatu yang penting dan konkret yang diperankan masyarakat setempat, yaitu "Pola Pembinaan Religiusitas Anak dalam Keluarga Muslim" (di kampung Kesisih, desa Bangunsari, Kecamatan Pageruyung, kabupaten Kendal). Norma kehidupan dan karakter budaya dalam masyarakat seperti ini menjadi penting dan relevan untuk diungkapkan dalam sebuah penelitian. Sebab sesungguhnya budaya pengasuhan orang tua dalam rangka membina religiusitas (keberagamaan) anak di setiap daerah yang ada di Indonesia ini dapat dikatakan memiliki ciri khas masing-masing, sehingga menggugah penulis untuk melakukan penelitan ini.

Tema pembinaan religiusitas menjadi permasalahan menarik untuk diteliti meskipun sudah ada bererapa penelitian tentang hal ini, misalnya penelitian yang dilakukan oleh Hepy Wahyuningsih 6 2009, dengan judul "Peran Orangtua Dalam Pembentukan Identitas Agama (Religious Identity Formation) Remaja”, yang mengkaji cara-cara efektif yang dilakukan orangtua dalam proses pembentukan identitas agama. Abdul Rahman Arsyad ${ }^{7}$ 2017, dengan judul "Pembinaan Keagamaan Anak Di

\footnotetext{
5 Mulyana, Deddy. 2004. Metodologi Kualitatif, (Paradigma Baru Ilmu Komunikasi dan Ilmu Sosial Lainnya). Bandung. Remaja Rosda Karya. h. 161

6 Hepi Wahyuningsih. Peran Orangtua dalam Pembentukan Identitas Agama (Religious Identity Formation) Remaja. Indigenous Jurnal Ilmiah Berkala Psikologi, Vol. 11, No. 1, Mei 2009, h. 47. http:// journals.ums.ac.id/index.php/indigenous/article/ view/1626/1156, 10 April 2019

7 Abdul Rahman Arsyad. Pembinaan Keagamaan Anak Di Lembaga Pemasyarakatan Di Kabupaten Bulukumba Dan Bantaeng. Jurnal Penelitian Pendidikan Agama dan Keagamaan, Vol. 15, No. 1 April 2017, h. 109. https://jurnaledukasikemenag.org/index.php/edukasi/ article/view/56, 10 April 2019
}

Lembaga Pemasyarakatan Di Kabupaten Bulukumba Dan Bantaeng" Efektifitas dan efesiensinya suatu kegiatan pembinaan, selayaknya para warga binaan pemasyarakatan dikelompokkan berdasarkan usia dan kasus. Sumber referensi masih didominasi dari bukubuku ilmu pengetahuan umum (keterampilan). Sedangkan untuk buku-buku agama terbilang belum ada, begitupun halnya dengan Iqra dan Qur'an terkadang pengadaannya dari inisiatif warga binaan pemasyarakatan sendiri.

Samsurijal $^{8}$ 2019, dengan judul "Pembinaan Keagamaan Peserta Didik Melalui Kegiatan Ekstrakulikuler Di Madrasah Ibtidaiyyah As'adiyah Banua Baru" mengatakan bahwa faktor-faktor yang mendukung pembinaan keagamaan adalah adanya dukungan penuh dari pihak yayasan dan kerjasama yang solid sesama tenaga pendidik. Sedangkan minimnya sumber dana dan sarana prasarana yang kurang memadai merupakan faktor yang menghambat pembinaan keagamaan.

Dari beberapa hasil penelitian tersebut di atas, penulis belum menemukan tulisan yang fokus pada persoalan proses dan implikasi implementasi pembinaan religiusitas dalam keluarga muslim di kampung Kesisih desa Bangunsari kecamatan Pageruyung kabupaten Kendal, meskipun ada tulisan yang lebih mendekatinya, yaitu tulisan Hepy Wahyuningsih.

\section{METODE PENELITIAN}

Dalam penelitian ini, penulis menggunakan jenis penelitian kualitatif dengan pendekatan etnografi. Nana Syaodih Sukmadinata menyebutkan definisi penelitian kualitatif sebagai berikut: Penelitian Kualitatif (Qualitative research) adalah suatu penelitian yang ditujukan untuk mendeskripsikan dan menganalisis fenomena, peristiwa, aktivitas

\footnotetext{
8 Samsu Rijal. Pembinaan Keagamaan Peserta Didik melalui Kegiatan Ekstrakulikuler di Madrasah Ibtidaiyyah As 'adiyah Banua. Jurnal Inspiratif Pendidikan, Vol. 8, No. 1 2019, h. 114. http://journal.uin-alauddin. ac.id/index.php/Inspiratif-Pendidikan/article/view/7841, 10 April 2019
} 
sosial, sikap, kepercayaan, persepsi, pemikiran, orang secara individual maupun kelompok. ${ }^{9}$ Sementara itu, pendekatan etnografi dipilih karena penelitian yang dilakukan berbasis masyarakat. Harris mengemukakan bahwa etnografi merupakan desain penelitian yang mendeskripsikan pola yang sama dari nilai, perilaku, keyakinan, dan bahasa dari kelompok yang berkebudayaan sama. ${ }^{10}$ Lebih lanjut lagi, Freankel dan Wallen mengemukakan tujuan dari pendekatan etnografi, yaitu memperoleh gambaran umum mengenai subyek penelitian yang menekankan pada aspek pemotretan pengalaman keseharian individu dengan cara observasi dan wawancara kepada mereka dan individu lainnya yang relevan. ${ }^{11}$ Jadi, pendekatan ini dipilih untuk menemukan cara masyarakat yang akan diteliti dalam menggunakan keyakinan dan pengetahuan mereka dalam membentuk religiusitas anak mereka.

Lokasi penelitian ini adalah Kampung Kesisih, desa Bangunsari, kecamatan Pageruyung. Kampung Kesisih merupakan salah satu kampung di mana wilayah tersebut relatif heterogen dari segi tingkat pendidikan, latar belakang golongan/kepercayaan ber-Islam, dan jenis pekerjaan. Hal tersebut tentu akan memberi warna berbeda pada cara mendidik atau membentuk religiusitas anak. Semakin heterogen suatu wilayah, maka semakin tinggi tekanan untuk melaksanakan tanggung jawab dalam mendidik anak.

Dalam penelitian ini, informan dipilih dengan cara snowball sampling, berdasarkan beberapa pertimbangan, yaitu: Pertama, para orang tua dari kalangan keluarga muslim yang memiliki anak usia 7-14 tahun, baik itu anak

9 Sukmadinata, Nana Syaodih. 2012. Metode Penelitian Pendidikan. Bandung: PT Remaja Rosdakarya. h. 60

10 Creswell, John W. 2014. Penelitian Kualitatif dan Desain Riset: Memilih di antara Lima Pendekatan. Yogyakarta: Pustaka Pelajar. h. 125

11 Creswell, John W. 2010. Research Design: Pendekatan Kualitatif, Kuantitatif, dan Mixed (Edisi Ketiga). Yogyakarta: Pustaka Pelajar. h. 294 laki-laki dan/atau anak perempuan. Kedua, keragaman golongan/organisasi keagamaan yang diikuti, karena cara pandang dan pola aktifitas keagamaan dari tiap golongan mempunyai corak yang berbeda dalam hal pengasuhan anak. Ketiga, keragaman tingkat pendidikan, mulai dari SD, SMP, SMA, sampai Perguruan Tinggi. Peneliti mengasumsikan bahwa semakin tinggi tingkat pendidikan orangtua, maka pola pikir dan cara yang digunakan dalam mendidik anak mereka akan lebih baik. Keempat, lama waktu bekerja orang tua (ayah/ibu), yaitu berapa lama waktu yang digunakan informan dalam bekerja. Peneliti mengasumsikan bahwa semakin lama waktu yang informan gunakan untuk bekerja, maka kesempatan untuk mendidik anak mereka semakin sedikit. Artinya, dengan kesibukan informan dalam pekerjaannya, peran informan dalam membentuk religiusitas anak akan semakin sedikit.

Teknik pengumpulan data melalui observasi, wawancara, dan dokumentasi. Untuk menguji keabsahan data dilakukan triangulasi baik dilakukan dengan cara memperpanjang waktu penelitian, maupun dengan menggunakan teknik ganda. Analisis data dilakukan sejak proses pengumpulan data, klasifikasi data, reduksi data, dan penarikan kesimpulan. Anlisis data yang digunakan dalam penelitian ini adalah Analysis Interactive Model dari Miles dan Huberman. Langkah-langkah dalam kegiatan analisis data meliputi: pengumpulan data (data collection), reduksi data (data reduction), penyajian data (data display), dan penarikan kesimpulan atau verifikasi (conclutions). Analisis data kualitatif dapat dilakukan berjalan bersamaan (secara simultan) dengan proses pengumpulan data berlangsung, interpretasi data, dan penulisan naratif lainnya.

\section{HASIL DAN PEMBAHASAN}

Sesuai dengan kriteria informan tersebut, terdapat 20 keluarga, namun hanya ada lima keluarga yang bersedia menjadi narasumber penelitian. Kelima keluarga tersebut akan penulis bahas lebih lanjut dalam sub bab uraian 
hasil penelitian ini. Karakteristik narasumber penelitian. Pertama, keluarga I, status keluarga utuh, umur 34 tahun, tingkat pendidikan Sarjana Strata satu, pekerjaan guru, memiliki anak usia 9 tahun, dengan kode HF; Kedua, keluarga II, status keluarga utuh, umur 41 tahun, tingkat pendidikan Sekolah Menengah Atas, pekerjaan wiraswasta, memiliki anak usia 12 tahun, dengan kode D; Ketiga, keluarga III, status keluarga tunggal (cerai mati), umur 51 tahun, tingkat pendidikan Sekolah Menengah Pertama, pekerjaan wiraswasta, memiliki anak usia 8 tahun, dengan kode RT; Keempat, keluarga IV, status keluarga tunggal (cerai hidup), umur 23 tahun, tingkat pendidikan Sekolah Menengah Atas, pekerjaan penjahit, memiliki anak usia 7 tahun, dengan kode RS; Kelima, keluarga $\mathrm{V}$, status keluarga tunggal (cerai hidup), umur 42 tahun, tingkat pendidikan Sekolah Dasar, pekerjaan dagang, memiliki anak usia 13 tahun, dengan kode RR.

\section{Kondisi Psikologis Keluarga}

Narasumber pertama berasal dari keluarga yang utuh, terdiri dari bapak, ibu dan anak. Bapak narasumber I ini merupakan seorang muslim yang taat beragama. Beliau berprofesi sebagai guru Agama di MI Muhammadiyah Bangunsari. Istrinya (ibu narasumber) memiliki profesi sebagai guru TK ABA. ${ }^{12}$

Kehidupan ekonomi mereka bertambah berat ketika kelahiran anak ke dua dengan menjalani operasi cesar. Ditambah setelah anak kedua lahir, anak tersebut menderita sakit kuning. Hal itu mengharuskan narasumber untuk bolak-balik kembali ke rumah sakit tempat anaknya dirawat untuk menjalani proses penyembuhan. Problem ekonomi jelas berpengaruh terhadap kondisi psikologis keluarga ini.

Narasumber kedua juga berasal dari keluarga yang utuh, selanjutnya disebut narasumber II. Narasumber II adalah muslim yang taat. Dari segi sosial keagamaan, dia memiliki idiologi keagamaan dan cara beribadah

\footnotetext{
12 wawancara narasumber I, 18 April 2019
}

yang sama dengan Muhammadiyah, sehingga dapat diklasifikasikan sebagai simpatisan Muhammadiyah. Dia seorang wirausaha di bidang jasa percetakan. Lokasi usahanya berada di luar kota, yakni di jakarta. Bapak Informan II harus rela meninggalkan keluarganya di kampung untuk bekerja di jakarta demi menafkahi dan memberi penghidupan kepada keluarganya dan pulang ke kampung setiap 2-3 bulan sekali.

Narasumber II menuturkan, bahwa sebenarnya aktifitas pekerjaan yang berada di luar kota tersebut jelas amat kurang nyaman bagi keluarganya. Sebab dia tidak bisa setiap waktu melihat tumbuh kembang anaknya, dan membina langsung perkembangan anaknya. ${ }^{13}$

Bagi narasumber II, prioritas utamanya adalah keluarga, dengan tetap mempertahankan pekerjaan. Karena dengan pekerjaan itu, dia dapat mengidupi anak-istrinya. Agar semua dapat berjalan, dalam hal-hal tertentu, dia berbagi tugas dengan istrinya.

Narasumber III adalah seorang wanita yang berstatus single parent atau janda. Dia berusia 51 tahun, dan memiliki tiga orang anak, dua laki-laki dan satu perempuan. Pendidikan yang ditempuhnya sekolah menengah pertama. Dia adalah seorang muslimah yang cukup taat menjalankan ajaran Islam. Dilihat dari aktifitas dan pengamalan ajaran Islam, dia termasuk diantara warga atau simpatisan Nahdlatul Ulama (NU). Mata pencaharian yang dijalani adalah berternak ayam, melanjutkan usaha yang dirintis suaminya sebelum meninggal. Sepeninggal suaminya, dia merasa sangat terpukul, karena pada saat itu anak-anaknya masih kecil dan masih membutuhkan banyak biaya untuk sekolah dan kebutuhan hidup sehari-hari. Karena itu, dia merasakan beban yang tidak ringan sebagai orang tua tunggal.

Sejak ditinggal suami, dia menyandang status sebagai janda dan sebagai orang tua tunggal. Tentu saja dengan status dan tanggungjawab mendidik dan menghidupi ketiga anaknya, dia merasa berat. Banyak

${ }^{13}$ wawancara narasumber II, 19 April 2019 
tekanan yang harus dia terima, yaitu dipandang sebelah mata karena statusnya sebagai janda, beban ekonomi keluarga, omongan tetangga yang tidak enak didengar, bahkan anaknya juga terkadang menjadi pergunjingan tetangga. Meskipun begitu, dia terus mencoba dan berusaha untuk menyesuaikan keadaan, dan secara perlahan melepaskan kesedihannya.

Adapun penyebab dari meninggalnya suami dari narasumber III adalah karena penyakit diabetes yang sudah lama diderita. Beberapa bulan sebelum meninggal suaminya sering keluar masuk rumah sakit, bahkan sampai rawat inap berminggu-minggu. Kondisi kesehatannya sempat mengalami pasang surut, namun pada akhirnya takdir bertaka lain, suaminya meninggal dunia, setelah mengalami koma selama beberapa hari.

Narasumber IV yang menjadi subjek penelitian ini adalah seorang yang berstatus janda karena bercerai dan berperan sebagai orang tua tunggal. Usianya relative masih muda yaitu berusia 23 tahun dengan seorang anak laki-laki. Beliau muslimah yang taat, dan salah satu aktifis Nasyi atul Aisyiyah/NA yaitu salah satu organisasi otonom dalam Persyarikatan Muhammadiyah di ranting desa Bangunsari dan berprofesi sebagai pedagang warung dan penjahit dengan menempati rumah yang sederhana.

Kisah perjalanan hidup narasumber IV ternyata cukup banyak tantangan yang berat. Pernikahan yang dijalaninya di usia muda, yakni saat masih duduk di kelas dua SMA dalam usia 17 tahun, memaksanya harus putus sekolah. Tidak berselang lama setelah nikah, dia pun melahirkan anak. Namun pernikahannya ternyata tidak bertahan lama, karena berakhir dengan perceraian. Karena itu, narasumber IV terpaksa menjanda dan menjadi single parent dalam mengasuh anaknya. Narasumber IV sudah menjalani sebagai orang tua tunggal selama 5 tahun menanggung biaya hidup keluarga dan juga pendidikan anaknya. ${ }^{14}$

Penyebab retaknya rumah tangga bermula

${ }^{14}$ wawancara narasumber IV, 16 April 2019 keadaan suaminya yang tidak memiliki pekerjaan tetap, selalu pulang malam dan uangnya sering dipakai untuk hal-hal yang tidak bermanfaat. Di siang hari dia terkadang hanya "kluntangklantung" menunggu panggilan bekerja sebagai kuli bongkar-muat pasir, maupun membantu tetangga yang sedang panen disawah. Ketika anaknya masih kecil, ia pernah meminta izin kepada istrinya akan meninggalkan kampung untuk merantau ke Jakarta untuk membantu saudaranya yang kebetulan memiliki usaha di sana. Namun melihat anaknya saat itu masih balita istri tidak memberikan izin kepada suaminya untuk merantau. Keadaan itu memicu ketidakharmonisan keluarga, bahkan menimbulkan keributan dan pertengkaran. Narasumber sering merasa tidak nyaman, karena pertengkaran itu sering terjadi di depan anaknya. Akhirnya, dia memutuskan untuk berpisah, sekalipun harus menanggung beban berat sebagai single parent yang menanggung kehidupan keluarga dan pendidikan anaknya.

Narasumber V juga merupakan seorang ibu yang berstatus sebagai janda dan single parent yang telah dijalaninya selama 10 tahun. Dia adalah seorang Muslimah yang taat beribadah, rajin shalat berjamaah di salah satu mushalla di kampung Kesisih. Dalam kehidupan sosial keagamaan, dia adalah simpatisan dari Muhammadiyah. Latar belakang pendidikan yang ditempuhnya adalah sekolah dasar, dan berprofesi sebagai pedagang sayur gendong keliling, dengan penghasilan tidak menentu. Di samping kondisi ekonomi yang tidak mencukupi kebutuhan keluarganya, dia juga harus merawat ibunya yang sudah tua dan sakit-sakitan. Dia terpaksa memilih bercerai dan hidup sebagai orang tua tunggal karena suaminya meninggalkan keluarga selama bertahun-tahun ke luar daerah, dan tiba-tiba secara sepihak menceraikannya. Kondisi ini tentu menimbulkan gangguan secara psikologi baik bagi dia sendiri maupun anaknya. ${ }^{15}$

Pasca perceraian dengan suami, narasumber $\mathrm{V}$ menyandang status sebagai

\footnotetext{
15 wawancara narasumber V, 16 April 2019
} 
single parent. Kehidupan semakin berat karena anaknya belum juga sadar bahwa orangtuanya sudah bercerai. Hampir satu tahun lamanya, anak saya selalu menanyakan di mana bapak. Narasumber sempat menitikkan air mata, dan tidak bisa menjawab pertanyaan putrinya. Namun bagaimanapun juga berita ini harus diketahui juga, yang selama ini dia selalu menutupi masalah keberadaan suaminya.

\section{Problem Pembinaan Religiusitas Anak}

Membina religiusitas anak memang bukan urusan yang mudah dan sederhana. Status keluarga sebagai keluarga utuh tidaklah serta merta berbanding lurus dengan mudahnya membina dan mendidik anak seperti yang banyak orang pikirkan dan bayangkan. Kesibukan orang tua baik ayah dan ibu yang sama-sama bekerja tentu menjadi salah satu penghambat pembinaan religiusitas kepada anak. Kebersamaan orang tua dan anak kadang menjadi amat terbatas sehingga mau tidak mau perhatian dan pantauan orang tua terhadap anak pun menjadi terbatas. Kurangnya waktu bersama-sama memang menghambat dalam pendidikan. Anak beliau agak sulit untuk dinasehati bahkan lebih senang main keluar rumah, bahkan cenderung terbawa dengan pergaulan yang kadang-kadang kurang baik dilingkungan sekitar. ${ }^{16}$

Jika sudah bersama teman-temannya, nasihat ataupun perintah apalagi larangan sudah sulit untuk disampaikan, anak dari narasumber I seperti kahilangan sikap segan kepada ayahnya. Tetapi ketika teman-temannya tidak sedang bersamanya maka nasihat dan pembinaan apapun termasuk pembinaan religiusitas kepada anak agak lebih bisa dia terima.

Intensitas kebersamaan antara orang tua dan anak di dalam keluarga dianggap memiliki perbedaan yang signifikan terhadap mudahnya seorang orang tua dalam membina religiusitas kepada anak. Narasumber II menginformasikan kepada penulis tentang munculnya kesulitan narasumber II dalam proses pembinaan nilainilai religiusitas pada anaknya. Jarangnya

\footnotetext{
${ }^{16}$ wawancara narasumber I, 18 April 2019
}

pertemuan antara ayah terhadap anaknya karena faktor pekerjaan serta masa pubertas anak seakan menjadi dilema bagi narasumber II. ${ }^{17}$

Di masa-masa anak sedang mengalami proses pendewasaan, seorang ayah malah tak bisa terus bersama untuk ikut di dalam proses pendidikan serta pembinaan religiusitas sang anak. Anak dari narasumber II terpaksa menjadikan orang lain sebagai sumber pendidikan atau sumber pembinaan terhadap dirinya yang kadang-kadang tidak sesuai dengan apa yang narasumber II pahami. Sehingga beliau menyadari bahwa tidak mudah menyampaikan pembinaan religiusitas secara instan, harus butuh kesabaran, ditambah kurangnya waktu untuk bersama.

Berbeda dengan narasumber I dan narasumber II yang merupakan keluarga utuh, narasumber III yang notabene merupakan kelurga tunggal juga memiliki problem yang tidak kalah memprihatinkan juga. Masalah awal masa menjadi orang tua tunggal adalah ketika ia harus menyesuaikan diri mengatasi masalah kenakalan anak, memenuhi kebutuhan keluarganya, sebab status yang disandangnya bukan hanya sebagai ibu bagi anak-anaknya akan tetapi ia juga menjadi ayah bagi anakanaknya. Oleh karena itu narasumber III harus memiliki dua bentuk sikap, sebagai wanita yang harus menjadi ibu yang bersikap lembut terhadap anaknya, dan sebagai ayah yang harus tegas dan memberikan arahan-arahan yang bermanfaat bagi anaknya, serat berperan sebagai penegak keadilan bagi rumah tangganya. ${ }^{18}$

Problem kelakuan anak merupakan salah satu hal yang narasumber III rasakan cukup berat, masa tumbuh-kembang anak yang sehat dan normal sesuai dengan dari jenis kelaminnya merupakan harapan setiap keluarga, namun itu tidak terjadi pada anak narasumber III. Anak ke tiga beliau yang lahir dengan jenis kelamin perempuan, rupanya memiliki kebiasaan berpakaian yang tidak wajar, dia suka memakai pakaian laki-laki dan memilih memotong

\footnotetext{
17 wawancara narasumber II, 19 April 2019

18 wawancara narasumber III, 15 April 2019)
} 
rambut seperti halnya seorang anak laki-laki.

Problem yang dihadapi narasumber IV juga nyaris serupa dengan narsumber III, yakni peran ganda yang dialami oleh narasumber IV sebagai single parent dirasakan sangat berat. Narasumber IV menyampaikan bahwa keluarga tanpa adanya sesosok bapak menjadi penghambat proses pendidikan dalam keluarga. Ia merasakan sangat berat, karena membimbing, membina dan menghidupi serta membesarkan sendirian anaknya. Ia harus bekerja pagi sampai sore di warungnya untuk bisa mencukupi kebutuhan mereka. Beruntung, narasumber IV memiliki orang tua yang pengertian. Beliau memasrahkan pendidikan agamanya kepada ibunya, walaupun ia memiliki keterbatasan waktu, ia juga masih terkadang memberikan nasihat-nasihat kepada anak-anaknya agar selalu menjaga sikap.

Narsumber IV menyadari bahwa peran ayah sejatinya sangat mendominasi terhadap kehidupan anak. Sehingga beliau menyadari bahwa tidak mudah membina religiusitas anak seperti menyampaikan nilai-nilai Islam pada anak tanpa bantuan suami.

Problematika seorang single parent juga dialami narasumber V. Masa-masa sulit yang dialami oleh informan $\mathrm{V}$ adalah proses pendidikan non formal yaitu proses pembinaan atau penanaman religiusitas pada anak. Tidak adanya sesosok ayah menjadi dilema tersendiri dalam pendidikan. Anak narasumber $V$ menjadi susah diatur dan seenaknya sendiri. Dari segi usia, anak narasumber $\mathrm{V}$ sedang mengalami masa pertumbuhan kepribadian sehingga susah dikontrol terutama apabila anak beliau sedang marah atau meminta sesuatu. Anak sering berontak terhadap apa yang disampaikan narasumber $\mathrm{V} .{ }^{19}$

Anak juga sering membandingkan apa yang narasumber $\mathrm{V}$ sampaikan dengan kehidupan teman-temannya yang masih memiliki keluarga lengkap. Hal ini memicu tidak tersampainya nilai-nilai Islam secara maksimal. Sehingga tidak jarang narasumber

\footnotetext{
19 wawancara narasumber V, 16 April 2019
}

$\mathrm{V}$ merasa putus asa dengan dirinya sendiri.

\section{Pola Pembinaan Religiusitas Anak}

Berdasarkan hasil data observasi dan wawancara yang telah dilakukan, maka hasil penelitian ini membuktikan bahwa pola pembinaan religiusitas anak di dalam keluarga muslim sangatlah berfariasi.

Menurut hasil pengamatan penulis, yang dapat penulis simpulkan dari pola yang digunakan narasumber pada keluarga I di dalam pembinaan religiusitas anak adalah pola pembinaan demokrasi, ia memberikan nasihat kepada anak-anaknya, memberikan pengarahan tentang bagaimana kewajiban sebagai orang islam, serta menerapkan aturan-aturan, namun posisi orang tua masih bersikap terbuka terhadap tuntutan dan pendapat yang dikemukakan anak, kemudian mendiskusikan hal tersebut bersama-sama. Hurlock berpandangan bahwa pola pembinaan demokrasi adalah salah satu teknik atau cara mendidik dan membimbing anak, di mana orang tua atau pendidik bersikap terbuka terhadap tuntutan dan pendapat yang dikemukakan anak, kemudian mendiskusikan hal tersebut bersamasama. Pola ini lebih memusatkan perhatian pada aspek pendidikan dari pada aspek hukuman, orang tua atau pendidik memberikan peraturan yang luas serta memberikan penjelasan tentang sebab diberikannya hukuman serta imbalan tersebut. ${ }^{20}$ Pola asuh demokrasi ditandai dengan sikap menerima, responsif, berorientasi pada kebutuhan anak yang disertai dengan tuntutan, kontrol dan pembatasan. Sehingga penerapan pola asuh demokrasi dapat memberikan keleluasaan anak untuk menyampaikan segala persoalan yang dialaminya tanpa ada perasaan takut, keleluasaan yang diberikan orang tua tidak bersifat mutlak akan tetapi adanya kontrol dan pembatasan berdasarkan norma-norma yang ada. $^{21}$

20 Hurlock. 2006. Psikologi Perkembangan : Pengantar Dalam Berbagai Bagiannya. Yogyakarta: UGM Press. h. 99

21 Hurlock. 2006. Psikologi Perkembangan : Pengantar Dalam.... h. 102 
Menurut hasil wawancara dan pengamatan penulis dari pembinaan keluarga II, pola pembinaan yang digunakan narasumber II cenderung berpola Otoriter. Karena kekhawatiran narasumber II terhadap anaknya, narasumber menerapkan aturan yang ketat dan kemauannya harus diikuti. Anak kedua narasumber lebih cenderung pendiam dan mengikuti aturan dan peritah dari ibunya. Lebih sering ia menghabiskan waktu dirumah, dan jarang juga ia meminta sesuatu seperti minta dibelikan mainan atau pakaian. Pada saat lulus SD si anak menginginkan untuk melanjutkan ke SMP terdekat supaya bisa tetap dekat dengan keluarga, namun berbeda hal dengan narasumber yang mengharuskan anaknya untuk masuk pondok pesantren. Narasumber selalu mengingatkan dan mengajarkan tentang bagaimana anak-anaknya agar paham akan wajibnya melaksanakan shalat lima waktu. Apabila tidak mengerjakan kewajiban yang diperintahkan Allah yang memang wajib dilaksanakan, maka tindakan yang harus dilakukan orang tua keluarga yaitu dengan menasehati dan memberikan teguran kepada sang anak. Namun, apabila anak tetap masih belum juga mau untuk melakukan kewajibannya tersebut maka narasumber terpaksa memukul anak, tentunya pada bagian yang tidak bahaya.

Melihat hasil analisis dari pembinaan narasumber II kepada anaknya memang agak berlebihan, anak dituntut untuk menyesuaikan diri dengan kemauan dan perintah sang ayah, bahkan juga harus berlawanan apa yang menjadi kemauan anak tersebut dan apa yang menjadi kemauan orang tua. Oleh karena itu pola pembinaan yang otoritatif seperti ini bisa saja membuat pribadi yang rumit. Analisis ini mendukung teori yang disampaikan oleh Purwadi, pola pembinaan otoriter ini dijelaskan sebagai pola pembinaan dengan disiplin yang ketat, orang tua senang mengawasi anakanak, orang tua enggan untuk berbicara dan mendengarkan pendapat sang anak, dan terkadang bersikap dingin kepada anakanak. Anak dari hasil dididkan yang otoritatif seperti ini cenderung tidak bahagia, tidak mudah bergaul dengan seusianya dan prestasi belajarnya rendah. ${ }^{22}$

Penulis juga dapat menarik kesimpulan bahwa pola pembinaan yang digunakan narasumber III adalah pola pembinaan permisif, ia membiarkan anaknya untuk bertindak sesuai dengan kemauan sang anak. Pola pembinaan ini memberi kebebasan kepada anak untuk melakukan apa kehendak mereka, orang tua tidak memberikan pengarahan dan aturan yang ketat, sehingga anak tersebut berprilaku sesuai dengan keinginannya sendiri walaupun terkadang bertolak belakang dengan norma yang ada. Menurut Elizabeth B Hurlock, ia mengatakan bahwa disiplin permisif ini tidak banyak disetujui secara sosial karena tidak menggunakan hukuman dalam kesalahan bertindak/berprilaku. Sedangkan menurut Dariyo, sifat dari pola pembinaan permisif ini adalah menetapkan segala peraturan kepada anak tersebut, menuruti keinginan anak dan memperbolehkan segala permintaan anak tersebut, maka peneliti menganggap bahwa pola pembinaan ini kurang tepat karena tidak mempertimbangkan keputusan yang diambil oleh anak, dan tidak memikirkan resiko apabila anak mengambil tindakan yang salah. ${ }^{23}$

Kemudian dari penuturan narasumber IV kepada penulis, dapat disimpulkan bahwa pola pembinaan yang digunakan narasumber IV adalah menggunakan pola otoriter. Rasa capek yang dirasakan selepas bekerja membuat narasumber tak jarang bersikap keras kepada anak, dengan memaksa anak untuk menuruti perintah narasumber dengan sedikit nada ancaman apabila anak sulit untuk diatur. Enung mengatakan ada beberapa pendekatan yang diikuti orang tua dalam berhubungan dan mendidik anak-anaknya salah satu di antaranya adalah sikap dan pendidikan otoriter. Pola pembinaan otoriter ditandai dengan ciri-ciri sikap orang tua yang kaku dan keras dalam

22 Purwadi, Proses Pembentukan Identitas Diri Remaja, Humantias: Indonesia sychology Journal Vol.I Januari 2004:43-52. 44.

${ }^{23}$ Agoes Dariyo, Psikologi Perkembangan Dewasa Muda (Jakarta : PT Gramedia Widiasarana, 2003) 
menjalankan peraturan-peraturan maupun disiplin. Orang tua bersikap memaksa dengan selalu menuntut kepatuhan anak agar bertingkah laku seperti yang dikehendaki oleh orang tuanya. Karena orang tua tidak mempunyai pegangan mengenai cara bagaimana mereka harus mendidik, maka timbullah berbagai sikap orang tua yang mendidik menurut apa yang dinggap terbaik oleh mereka sendiri, diantaranya adalah dengan hukuman dan sikap acuh tak acuh, sikap ini dapat menimbulkan ketegangan dan ketidak nyamanan, sehingga memungkinkan kericuhan di dalam rumah. ${ }^{24}$ Pendapat ini sepaham dengan pendapat Shapiro bahwa orang tua otoriter berusaha menjalankan rumah tangga yang didasarkan pada struktur dan tradisi, walaupun dalam banyak hal tekanan mereka akan keteraturan dan pengawasan membebani anak. ${ }^{25}$

Pola pembinaan yang digunakan narasumber $\mathrm{V}$ dapat disimpulkan yaitu adalah pola pembinaan yang Permisif. Narasumber tergolong jarang melakukan pembinaan religiusitas kepada anaknya, karena minimnya pengetahuan agama yang dimiliki. Narasumber kerap memberi kebebasan yang penuh dan diijinkan membuat keputusan sendiri tanpa mempertimbangkan orang tua serta bebas menuruti apa yang diinginkan. Pola asuh permisif dikatakan pola asuh tanpa disiplin sama sekali. Orang tua enggan bersikap terbuka terhadap tuntutan dan pendapat yang dikemukakan anak. Menurut Kartono dalam pola pembinaan permisif, orang tua memberikan kebebasan sepenuhnya dan anak diijinkan membuat keputusan sendiri tentang langkah apa yang akan dilakukan, orang tua tidak pernah memberikan pengarahan dan penjelasan kepada anak tentang apa yang sebaiknya dilakukan anak. Dalam pola asuh permisif hampir tidak ada komunikasi antara anak dengan orang tua

24 Enung Fatimah, Psikologi Perkembangan : Perkembangan Peserta Didik (Bandung : Pustaka Setia 2008) hlm. 85

25 Saphiro, Mengajarkan Emosional Inteligensi Pada Anak (Bandung : Rosdakarya. 2009) hlm. 29 serta tanpa ada disiplin sama sekali. ${ }^{26}$

\section{KESIMPULAN}

Hasil penelitian dapat disimpulkan bahwa kondisi psikologi keluarga muslim di kampung kesisih begitu bervariasi, sesuai dengan latar belakang tiap-tiap keluarga. Permasalahan orang tua dengan kondisi ekonomi yang kurang mencukupi dan jarak lokasi perkerjaan yang jauh dengan keluarga, merupakan hal yang dialami oleh orang tua dengan status keluarga utuh. Sedangkan orang tua dengan status single parent memiliki potensi lebih banyak merasakan trauma dan kekecewaan yang mendalam dalam kehidupannya.

Status keluarga sebagai keluarga utuh tidaklah serta-merta berbanding lurus dengan mudahnya membina dan mendidik anak. Beberapa kesulitan muncul dalam proses pembinaan religiusitas pada anak. Kesulitan tersebut diantaranya kurangnya kebersamaan orang tua dan anak karena kesibukan pekerjaan, adanya pegaruh lingkungan sekitar dan pergaulan teman sebaya yang dapat menghambat proses pembinaan religiusitas. Selain itu, tidak adanya sesosok ayah sebagai panutan dalam keluarga menjadikan proses pembinaan religiusitas tidak berjalan dengan maksimal.

Ditemukan beberapa pola pembinaan religiusitas keluarga muslim di kampung kesisih yang telah diterapkan kepada anakanaknya. Pola tersebut adalah pola pembinaan demokrasi, pola pembinaan otoriter dan pola pembinaan permisif. Akhirnya kedekatan orang tua dan komunikasi yang baik akan membantu suksesnya orang tua dalam membina religiusitas anak di dalam keluarga.

\section{DAFTAR PUSTAKA}

Abdul Rahman Arsyad. Pembinaan Keagamaan Anak Di Lembaga Pemasyarakatan Di Kabupaten Bulukumba Dan Bantaeng. Jurnal Penelitian Pendidikan Agama dan

26 Enung Fatimah, Psikologi Perkembangan : Perkembangan........ hlm. 85 
Keagamaan, Vol. 15, No. 1 April 2017, h. 109. https://jurnaledukasikemenag.org/ index.php/edukasi/article/view/56, 10 April 2019

Agoes Dariyo, 2003. Psikologi Perkembangan Dewasa Muda. PT Gramedia Widiasarana, Jakarta

Deddy Mulyana, 2004. Metodologi Kualitatif, (Paradigma Baru Ilmu Komunikasi dan Ilmu Sosial Lainnya). Remaja Rosda Karya, Bandung.

Departemen Agama RI, 2004. Al-Qur 'an dan Terjemahnya. Departemen Agama RI, Jakarta.

Enung Fatimah, 2008. Psikologi Perkembangan: Perkembangan Peserta Didik. Pustaka Setia, Bandung.

Hepi Wahyuningsih. Peran Orangtua dalam Pembentukan Identitas Agama (Religious Identity Formation) Remaja. Indigenous Jurnal Ilmiah Berkala Psikologi, Vol. 11, No. 1, Mei 2009 ,h. 47.http://journals. ums.ac.id/index.php/indigenous/article/ view/1626/1156, 10 April 2019

Hurlock. 2006. Psikologi Perkembangan : Pengantar Dalam Berbagai Bagiannya. UGM Press, Yogyakarta.

John W Creswell, 2010. Research Design: Pendekatan Kualitatif, Kuantitatif, dan Mixed (Edisi Ketiga). Pustaka Pelajar, Yogyakarta.
John W Creswell, 2014. Penelitian Kualitatif dan Desain Riset: Memilih di antara Lima Pendekatan. Pustaka Pelajar, Yogyakarta.

Muh Anis, 2009. Sukses Mendidik Anak. PT Pustaka Insan Madani, Yogyakarta.

Muhaimin dkk, 2002. Paradigma Pendidikan Islam: (Upaya mengefektifkan Agama Islam di Sekolah). Remaja Rosda Karya, Bandung.

Nana Syaodih Sukmadinata, 2012. Metode Penelitian Pendidikan. PT Remaja Rosdakarya, Bandung.

Purwadi. Proses Pembentukan Identitas Diri Remaja. Humantias: Indonesia sychology Journal Vol.I Januari 2004:43-52. 44.

Samsurijal. Pembinaan Keagamaan Peserta Didik melalui Kegiatan Ekstrakulikuler di Madrasah Ibtidaiyyah As 'adiyah Banua. Jurnal Inspiratif Pendidikan, Vol. 8, No. 1 2019, h. 114. http://journal.uin-alauddin. ac.id/index.php/Inspiratif-Pendidikan/ article/view/7841, 10 April 2019

Saphiro, 2009. Mengajarkan Emosional Inteligensi Pada Anak. Rosdakarya, Bandung. 